\title{
Upregulation of the Voltage-Gated Sodium Channel $\beta 2$ Subunit in Neuropathic Pain Models: Characterization of Expression in Injured and Non-Injured Primary Sensory Neurons
}

\author{
Marie Pertin, ${ }^{1,2}$ Ru-Rong Ji, ${ }^{3}$ Temugin Berta, ${ }^{1,2}$ Andrew J. Powell, ${ }^{4}$ Laurie Karchewski, ${ }^{6}$ Simon N. Tate, ${ }^{4}$ Lori L. Isom, ${ }^{5}$ \\ Clifford J. Woolf, ${ }^{6}$ Nicolas Gilliard, ${ }^{1}$ Donat R. Spahn, ${ }^{1}$ and Isabelle Decosterd ${ }^{1,2}$ \\ ${ }^{1}$ Anesthesiology Pain Research Group, Department of Anesthesiology, Lausanne University Hospital, CH-1011 Lausanne, Switzerland, ${ }^{2}$ Department of Cell \\ Biology and Morphology, Faculty of Biology and Medicine, Lausanne University, CH-1005 Lausanne, Switzerland, ${ }^{3}$ Pain Research Center, Department of \\ Anesthesiology, Brigham and Women's Hospital and Harvard Medical School, Boston, Massachusetts, 02115, ${ }^{4}$ Gene Expression and Protein Biochemistry \\ Department, GlaxoSmithKline Research and Development, Stevenage, Hertfordshire SG1 2NY, United Kingdom, ${ }^{5}$ Department of Pharmacology, The \\ University of Michigan, Ann Arbor, Michigan 48109-0632, and Neural Plasticity Research Group, Department of Anesthesia and Critical Care, \\ Massachusetts General Hospital and Harvard Medical School, Boston, Massachusetts 02921
}

The development of abnormal primary sensory neuron excitability and neuropathic pain symptoms after peripheral nerve injury is associated with altered expression of voltage-gated sodium channels (VGSCs) and a modification of sodium currents. To investigate whether the $\beta 2$ subunit of VGSCs participates in the generation of neuropathic pain, we used the spared nerve injury (SNI) model in rats to examine $\beta 2$ subunit expression in selectively injured (tibial and common peroneal nerves) and uninjured (sural nerve) afferents. Three days after SNI, immunohistochemistry and Western blot analysis reveal an increase in the $\beta 2$ subunit in both the cell body and peripheral axons of injured neurons. The increase persists for $>4$ weeks, although $\beta 2$ subunit mRNA measured by real-time reverse transcriptionPCR and in situ hybridization remains unchanged. Although injured neurons show the most marked upregulation, $\beta 2$ subunit expression is also increased in neighboring non-injured neurons and a similar pattern of changes appears in the spinal nerve ligation model of neuropathic pain. That increased $\beta 2$ subunit expression in sensory neurons after nerve injury is functionally significant, as demonstrated by our finding that the development of mechanical allodynia-like behavior in the SNI model is attenuated in $\beta 2$ subunit null mutant mice. Through its role in regulating the density of mature VGSC complexes in the plasma membrane and modulating channel gating, the $\beta 2$ subunit may play a key role in the development of ectopic activity in injured and non-injured sensory afferents and, thereby, neuropathic pain.

Key words: pain; neuropathic pain; sodium channel; $\beta$ subunit; nerve injury; animal model

\section{Introduction}

Neuropathic pain occurs as a consequence of lesions or dysfunction of the nervous system and is characterized by spontaneous pain, allodynia, and hyperalgesia. After peripheral nerve injury, ectopic discharge in primary sensory neurons may directly initi-

Received March 23, 2005; revised 0ct. 12, 2005; accepted 0ct. 12, 2005.

This work was supported by Swiss National Science Foundation Grant 3232-066354/3200-066355 (I.D.), the Pierre Mercier Science Foundation (I.D.), the Swiss Society of Anesthesiology (I.D.), National Institutes of Health Grants NS040698 (R.-R.J.) and NS039518 (C.J.W.), and National Multiple Sclerosis Society Grant RG2882 (L.I.). We thank Egbert Welker for his critical reading of this manuscript, Michael Costigan, Romano Regazzi, and Severine Cheviet for scientific advice, Nadège Roduit for technical assistance, Eric Bernardi and Susan Lewis for editorial assistance, and Jean-Yves Chatton and Yannick Krempp for the use and advice at the Cellular Imaging Facility at the University of Lausanne.

Correspondence should be addressed to Isabelle Decosterd, Anesthesiology Pain Research Group, Department of Anesthesiology, Lausanne University Hospital and Department of Cell Biology and Morphology, Lausanne University, Bugnon 9, CH-1005 Lausanne, Switzerland. E-mail: isabelle.decosterd@chuv.ch.

DOI:10.1523/JNEUROSCI.3066-05.2005

Copyright $\odot 2005$ Society for Neuroscience 0270-6474/05/2510970-11\$15.00/0 ate spontaneous pain (Wall and Devor, 1983; Price et al., 1989). Abnormal excitability in the injured primary sensory neurons occurs at the neuroma, along the axons, and in the dorsal root ganglia (DRGs), as well as in adjacent intact afferents (Wall and Devor, 1983; Wu et al., 2001; Ma et al., 2003; Amir et al., 2005). Spontaneous afferent inflow from both injured and non-injured A- and C-fibers may also generate activity-dependent changes in dorsal horn neurons (Amir and Devor, 2000; Gold, 2000; Wu et al., 2001).

Voltage-gated sodium channels (VGSCs) are responsible for the generation and propagation of action potentials in the membranes of most neurons and excitable cells. The VGSC is composed of a combination of pore-forming $\alpha$ subunits and auxiliary $\beta$ subunits. Ten genes encoding the selective pore-forming $\alpha$ subunits have been identified, and both tetrodotoxin (TTX)sensitive $\alpha$ subunits $\left(\mathrm{Na}_{\mathrm{v}} 1.7, \mathrm{Na}_{\mathrm{v}} 1.1, \mathrm{Na}_{\mathrm{v}} 1.6, \mathrm{Na}_{\mathrm{v}} 1.2\right.$, and $\left.\mathrm{Na}_{\mathrm{v}} 1.3\right)$ and TTX-resistant $\alpha$ subunits $\left(\mathrm{Na}_{\mathrm{v}} 1.8\right.$ and $\left.\mathrm{Na}_{\mathrm{v}} 1.9\right)$ have been 
identified in DRG neurons (Black et al., 1996; Amaya et al., 2000; $\mathrm{Yu}$ and Catterall, 2004). The mature channel in the plasma membrane is composed of an $\alpha$ subunit associated with a disulfidelinked $\beta 2$ or $\beta 4$ subunit and a noncovalently linked $\beta 1$ or $\beta 3$ subunit (Isom et al., 1992, 1995; Morgan et al., 2000; Yu et al., $2003)$. All known $\beta$ subunits $(\beta 1-\beta 4)$ are expressed in primary sensory neurons, and recent findings suggest that $\beta 3$ and $\beta 4$ may substitute for $\beta 1$ and $\beta 2$, respectively, in some sodium channels (Morgan et al., 2000; Yu et al., 2003).

Altered neuronal excitability after peripheral nerve injury may depend to a considerable extent on injury-induced modulation of VGSC expression and trafficking in primary sensory and dorsal horn neurons (Hains et al., 2004; Wood et al., 2004). Coexpression of $\beta 2$ subunits with $\alpha$ subunit channels in cell expression systems and studies of null mutant mice have demonstrated the role of the $\beta 2$ subunit in voltage dependence of channel activation and inactivation and augmentation of channel density at the plasma membrane (Isom et al., 1995; Chen et al., 2002). Based on these results, we investigated whether the $\beta 2$ subunit may be involved in abnormal neuronal excitability in injured and noninjured neurons after peripheral nerve injury.

We have examined changes in $\beta 2$ subunit expression in primary sensory neurons and their peripheral axons in two models of neuropathic pain: the spared nerve injury (SNI) model, in which the common peroneal and tibial nerves are severed leaving the sural nerve intact, and the L5 spinal nerve ligation (SNL) model (Kim and Chung, 1992; Decosterd and Woolf, 2000). Both models allow analysis of changes in injured and non-injured primary sensory neurons. To study whether altered $\beta 2$ subunit expression has functional consequences, neuropathic pain-related behavior after SNI was investigated in $\beta 2$ subunit null mutant mice (Chen et al., 2002).

\section{Materials and Methods}

Animals and surgery. Experiments were performed in 200-250 g adult male Sprague Dawley rats (Charles River France, L'Abresle, France). Adult wild-type C57BL/6 mice and $\beta 2$ subunit null mutant mice (B6.129-Scn2b ${ }^{\text {tm1Lli }}$, backcrossed over 12 generations with C57BL/6 mice) (Chen et al., 2002) were included in a subset of behavioral experiments. All procedures were approved by the Committee on Animal Experimentation of the canton of Vaud, Switzerland, in accordance with the Swiss Federal Law on Animal Welfare and the guidelines of the International Association for the Study of Pain (Zimmermann, 1983). Animals were housed under a $12 \mathrm{~h}$ light/dark cycle and had access to water and food ad libitum.

Surgical and injection procedures were performed under $1.5-2.5 \%$ isoflurane (Abott, Baar, Switzerland) general anesthesia as described previously (Decosterd et al., 2002). Briefly, after exposure of the sciatic nerve by an incision of the biceps femoris, the sciatic nerve was ligated by a 5.0 silk suture (Ethicon; Johnson \& Johnson, Brussels, Belgium) and transected for the total axotomy model. For the SNI model, the common peroneal and tibial nerves were ligated with 5.0 silk suture and transected, and a $3 \mathrm{~mm}$ portion of the nerves was removed. To produce an SNL, L4 and L5 transverse processes were exposed and an L5 hemilaminectomy was performed to access the L4 and L5 spinal nerves. The L5 spinal nerve was then tightly ligated with 6.0 silk thread. Muscle and skin were closed in two distinct layers with 5.0 silk threads and wound clips, respectively, in all procedures. Sham surgeries for control groups were similarly performed without nerve injury. Fluorogold (FG) (2.5\%; Fluorochrome, Denver, CO) was injected (eight times, $1 \mu \mathrm{l}$ ) in the sural skin territory of a subgroup of SNI-operated or control rats for retrograde tracing and identification of neurons of non-injured sural nerve. In addition, we used the unilateral arthritis complete Freund's adjuvant (CFA) model of inflammation consisting of a single injection of $50 \mu \mathrm{l}$ of CFA (Sigma, St. Louis, MO) into the plantar surface of the hindpaw.
Animals were allowed to survive for $1,3,5,7,14,21$, or $28 \mathrm{~d}$ ( $n=3-12$ in treated and control groups at all time points and type of analysis).

$\beta 2$ antibodies. Several anti- $\beta 2$ subunit antibodies have been used in the present study. Antibodies were raised in rabbits against the human (GW83 and GW93) and the rat (GW2690) C-terminal cytoplasmic tail of $\beta 2$ subunit using the peptides CVRRKKEQKLSTDDLKTEEEGKTDGEGNPDDGAK (GW83 and GW93) (Coward et al., 2001) and EGKTDGEGNAEDGAK (GW2690). $\beta 2$-ec antibody, a generous gift from the laboratory of W. A. Catterall (University of Washington, Seattle, WA), was generated using a peptide corresponding to the extracellular residues $59-73$ of the rat sodium channel $\beta 2$ subunit (INLKLERFGDRVEFS) (Chen et al., 2002). None of the immunizing peptide sequences chosen have similarities with the sequences of the $\beta 1, \beta 3$, and $\beta 4$ subunits. In addition to standard controls excluding primary antibody from reactions, characterization, and controls included incubation of blot membrane (GW93) or tissue sections (GW83) with $\beta 2$ antibody preabsorbed for $1 \mathrm{~h}$ at room temperature (RT) with incremental concentrations (1$100 \mathrm{~nm}$ ) of respective immunizing peptides. Western blot analyses were performed on proteins extracted from cell lines stably expressing the individual $\beta$ subunits (isolated after transfection of human embryonic kidney HEK293 with control vector, $\mathrm{pCIH}-\beta 1, \mathrm{pCIH}-\beta 2$, and $\mathrm{pCIH}-\beta 3$ ) (Meadows et al., 2002) and from brain tissue of adult $\beta 2$ subunit $-/-$ mice and control wild-type mice.

Western blots. L4/L5 DRGs and nerves were homogenized and lysed in a solution of $2 \%$ SDS, $20 \%$ glycerol, and $100 \mathrm{~mm}$ Tris- $\mathrm{HCl}$, pH 6.8 , containing a protease inhibitor mixture (Complete; Roche Diagnostics, Rotkreuz, Switzerland). The homogenate was centrifuged at 10,000 $\times g$ for $20 \mathrm{~min}$ at $4^{\circ} \mathrm{C}$, and protein concentration in supernatant was determined by the Bradford method (Protein Assay; Bio-Rad, München, Germany). The molecular weight of $\beta 2$ subunit depends on the tissue (above $30 \mathrm{kDa}$ in cell extracts/brain samples, at $25 \mathrm{kDa}$ in DRG samples). This suggests different levels of glycosylation in the different tissues. To deal with this, an additional deglycosylation step was added for processing brain and cell extracts by incubating the lysate with $500 \mathrm{U}$ of PNGase F enzyme in buffers supplied by the manufacturer (New England Biolabs, Frankfurt am Main, Germany) for $1.5 \mathrm{~h}$ at $37^{\circ} \mathrm{C}$. Then, $1 \mu \mathrm{l}$ of $\beta$-mercapto-ethanol and $1 \mu \mathrm{l}$ of $1 \%$ bromophenol blue were added for each $40 \mu \mathrm{g}$ of protein sample and incubated $3 \mathrm{~min}$ at $100^{\circ} \mathrm{C}$ for denaturation. A subcellular fractionation of cytosolic and plasma membrane proteins using ultracentrifugation was performed for a subset of samples: DRGs were lysed in a cold lysis buffer (10 mm Tris, pH 7.5, $300 \mathrm{~mm}$ sucrose, $1 \mathrm{~mm}$ EDTA, and protease inhibitor mixture) at $4^{\circ} \mathrm{C}$, sonicated, and centrifuged at $6000 \times g$ for $5 \mathrm{~min}$. The supernatant was then centrifuged at $100,000 \times g$ for $1 \mathrm{~h}$. The pellet of membrane proteins was washed, centrifuged at $100,000 \times g$, and resuspended in lysis buffer.

Proteins were separated on 10\% SDS-PAGE gel and transferred to polyvinylidene difluoride membrane with a Semidry Transfer System (Bio-Rad, München, Germany). Membranes were blocked at RT for 30 min in 5\% milk in PBS containing 0.2\% Tween-20, followed by incubation with $\beta 2$ antibody (GW93, 1:1000; GW2690, 1:75; and $\beta 2$-ec, 1:250) overnight at $4^{\circ} \mathrm{C}$. The blots were then incubated for $90 \mathrm{~min}$ at RT with HRP-conjugated goat anti-rabbit secondary antibody (1:2000; Dako, Glostrup, Denmark), developed using enhanced chemiluminescence solution (ECL Plus; Amersham Biosciences, Little Chalfont, UK) for 5 min at RT, and exposed on films (BioMax MR Film; Eastman Kodak, Rochester, NY) for $30 \mathrm{~s}$ to 15 minutes. Blots were stripped and reprobed with extracellular signal-regulated kinase 1/2 (ERK1/ERK2) antibody diluted at 1:3000 (Cell Signaling Technology, Beverly, MA) or glyceraldehyde-3phosphate dehydrogenase (GAPDH) antibody at 1:1,000,000 (Abcam, Cambridge, UK). Constitutively expressed ERK1/ERK2 is not regulated by nerve injury and has served as a convenient protein loading control (Zhuang et al., 2005). To confirm that ERK1/ERK2 protein levels are unaltered by nerve injury, a control using GAPDH as an internal control on the same membrane was performed (Fig. $1 E$ ). We find no difference in the relative amounts of ERK and GAPDH in control and DRGs from animals after SNI.

For analysis and quantification, films were scanned and the density of specific bands was measured and normalized with the corresponding loading control ERK2 band (Scion Image software; Scion, Frederick, MD). 
A

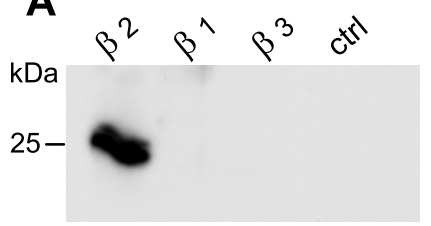

Transfected HEK cells with $\beta 1,2$ or 3

B

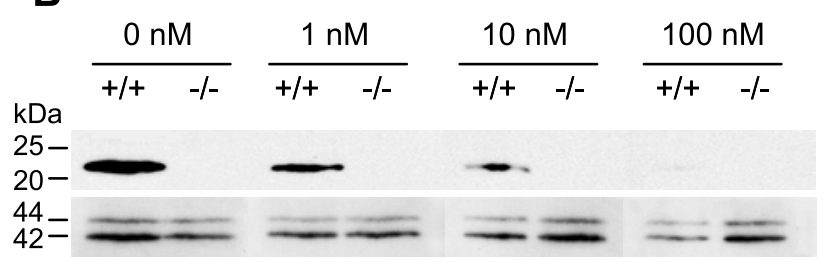

C

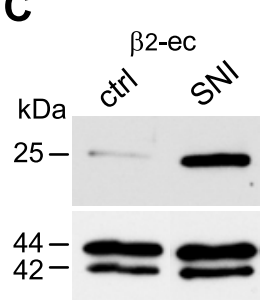

D

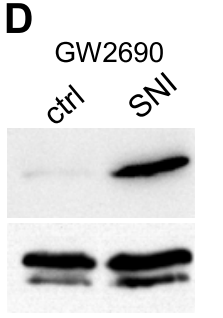

E

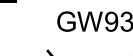

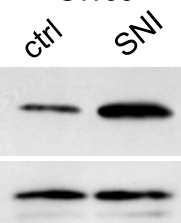

$\beta 2$

ERK1

ERK2

GAPDH

Figure 1. Spared nerve injury increases expression of the $\beta 2$ subunit of VGSCs in the DRGS. $\boldsymbol{A}$, Deglycosylated lysates of HEK293 cells transfected with $\beta 2, \beta 1$, or $\beta 3$ subunit expression constructs or control expression vector only (ctrl). A single band is detected in $\beta 2$-expressing cells only (GW93 antibody). $\boldsymbol{B}$, Immunoblot with GW93 anti- $\beta 2$ subunit antibody on deglycosylated brain tissue from $\beta 2$ subunit null mutant $(-/-)$ or wild-type $(+/+)$ mice. The antibody was preincubated with a specific $\beta 2$ peptide at increasing concentrations ( $0-100 \mathrm{~nm})$ before Western blotting. $(-\boldsymbol{E}$, Three antibodies specific for the $\beta 2$ subunit all recognize a single band at $25 \mathrm{kDa}$ in Western blot analyses of L4/L5 DRG tissue from SNI-operated and control rats. Enhanced $\beta 2$ subunit immunoreactivity 1 week after SNI is observed using $\beta 2$ subunit $\beta 2$-ec (C), GW2690 (D), and GW93 (E) antibodies. To control for loading, the same blots were reprobed with an antibody recognizing both ERK1 (44 kDa) and ERK2 (42 kDa), which are constitutively expressed (bottom or middle panels in $\boldsymbol{B}-\boldsymbol{E}$ ) and confirmed with an GAPDH antibody ( $37 \mathrm{kDa}$ ) ( $E$, bottom panel).

Immunohistochemistry. Rats were terminally anesthetized with pentobarbital sodium $(100 \mathrm{mg} / \mathrm{kg}$, i.p) and transcardially perfused with $0.9 \%$ saline, followed by $4 \%$ paraformaldehyde in $0.1 \mathrm{~m}$ phosphate buffer (PB), pH 7.4. L4 and L5 DRGs and nerves (sural alone or tibial and common peroneal nerves) were dissected, postfixed at $4^{\circ} \mathrm{C}$ for additional $90 \mathrm{~min}$ in the same fixative solution, and transferred into $20 \%$ sucrose $0.1 \mathrm{M} \mathrm{PB}$ overnight. DRGs and nerves were mounted in O.C.T. compound (Tissue-Tek; Sakura Finetek, Zoeterwoude, The Netherlands). Tissue obtained from peripheral nerve injury and control groups were embedded in the same mold, frozen on dry ice, serially cryosectioned parallel to the direction of nerve fibers at $12 \mu \mathrm{m}$ of thickness, and deposed on Superfrost plus-coated slides. Tyramide system amplification (TSA+ Fluorescence systems; NEN Life Science, Boston, MA) followed by direct immunofluorescence was used for coimmunodetection of $\beta 2$ subunits with other markers (Amaya et al., 2000). Sections were incubated for $30 \mathrm{~min}$ at $37^{\circ} \mathrm{C}$ in phenylhydrazin $(0.1 \%$ in PBS). After three washing steps with TNT buffer ( $0.15 \mathrm{M} \mathrm{NaCl}, 0.1 \mathrm{~m}$ Tris-HCl, pH 7.5, and 0.05\% Tween 20), sections were blocked for $30 \mathrm{~min}$ at RT in TNB buffer $(0.5 \%$ blocking reagent provided by the manufacturer, $0.15 \mathrm{M} \mathrm{NaCl}, 0.1 \mathrm{~m}$ Tris- $\mathrm{HCl}, \mathrm{pH}$ 7.5 , and $0.5 \%$ Tween 20 ) and then incubated overnight at $4^{\circ} \mathrm{C}$ with $\beta 2$ GW83 antibody (1:1000). After washing, sections were incubated with biotin-conjugated anti-rabbit secondary antibody (Vector Laboratories, Burlingame, CA) at a dilution of 1:200 in TNB buffer for $2 \mathrm{~h}$ at RT, and then another incubation with streptavidin-HRP (provided in TSA + kit) at 1:100 in TNB buffer was performed for $30 \mathrm{~min}$ at RT. Finally, tyramide was added (1:50 in amplification diluent buffer) to slides for $8 \mathrm{~min}$ at RT.

Direct fluorescent immunohistochemistry (IHC) was conducted thereafter. Sections were reblocked for $30 \mathrm{~min}$ in PBS 10\% normal goat serum and $0.3 \%$ Triton X-100 and incubated overnight at $4^{\circ} \mathrm{C}$ with mouse anti-neurofilament-200 (NF-200) antibody (1:500; Sigma) or rabbit anti-activating transcription factor 3 (ATF3) antibody (1:500; Santa Cruz Biotechnology, Santa Cruz, CA). Sections were washed three times in PBS and incubated for 90 min at RT with corresponding FITCconjugated secondary antibody (Vector Laboratories). Direct fluorescent IHC was used for $\beta 2$ subunit simple detection in DRGs and nerves using the same protocol with the exception that GW83 antibody was used at 1:100 dilution and sections were incubated at $4^{\circ} \mathrm{C}$ for $36 \mathrm{~h}$. Slides were mounted with Vectashield mounting medium (Vector Laboratories).

Immunostained DRG sections were examined with an epifluorescent microscope (AxioPlan; Zeiss, Feldbach, Switzerland) under the appropriate filters, and images were recorded by digital camera using the same conditions (e.g., exposure and gain) for injured and control sections (AxioCam; Zeiss). Intensity and cell area were measured with analySIS software (Soft Imaging System, Münster, Germany), and the number of labeled neuronal profiles was counted in a blinded manner. For quantification, a slide from the first 10 sections was randomly selected, and then four sections were selected every fifth DRG section from the series of consecutive serially cut sections. Immunoreactive (IR) cell profiles were counted in each DRG section and expressed as the percentage of total neuronal cell profiles or for colocalization studies as the percentage of ATF3 neuronal profiles (for tibial and peroneal injured cells) and Fluorogold profiles (for sural non-injured cells). DRGs from three to four animals were analyzed in each treatment group. To construct profile size distribution histograms, four sections were similarly selected from each animal $(n=4)$, labeled neurons in a $10 \times$ optic field were identified, and the cross-sectional areas (in square micrometers) were measured (Decosterd et al., 2002).

Nerve sections were examined with a confocal laser scanning microscope (LSM 510 Meta Confocal Microscope; Zeiss). Images were taken through the central plane of the nerve at a thickness of $0.8 \mu \mathrm{m}$, and long parts of the nerves were scanned with the same parameters of image acquisition in controls and SNI sections. A montage of images along the nerve was made with Adobe Illustrator (Adobe Systems, San Jose, CA).

Real-time reverse transcription-PCR. Ipsilateral L4 and L5 DRGs were rapidly dissected and kept in RNA-later solution (Qiagen, Basel, Switzerland) to prevent degradation. Total RNA from each animal was isolated using RNeasy Mini kit (Qiagen), with a DNase step (RNase free DNase set; Qiagen) directly on column. Extracted RNA was eluted, and optical density was measured using $260 \mathrm{~nm}$ absorbance spectrophotometry and RNA quality controlled by gel electrophoresis. A total of $1.5 \mu \mathrm{g}$ of RNA was reverse transcribed using Omniscript reverse transcriptase according to the protocol of the manufacturer (Qiagen).

Primer and probe sequences were designed using Beacon Designer 3.0 software (Premier Biosoft International, Palo Alto, CA) according to specification for SYBR-green (Vandesompele et al., 2002). Sequences for the forward primer and reverse primer are as follow: $5^{\prime}$-GATGTTCCTCCAGTTCCGAATG-3' and ' $5^{\prime}$-GGGTTCCCCGAGAACTCTAC-3' for $\beta 2 ; 5^{\prime}$ GGCTCATTAAATCAGTTATGGTTCCT-3' and $5^{\prime}$-TCTCTGACCTCTTTCCCTTTGATTTC-3' for $\mathrm{Na}_{\mathrm{v}} 1.3 ; 5^{\prime}$-TCCCGGACAAATCAGAAACTG-3' and 5'-GCCCCTGGTGACACTGTCA-3' for $\mathrm{Na}_{\mathrm{v}} 1.8$; and $5^{\prime}$-CCCCCAATGTATCCGTTGTG-3' and 5' -TAGCCCAGGATGCCCTTTAGT-3' for GAPDH. GAPDH expression is not altered in our experimental conditions and was used as an endogenous control to normalize expression levels of sodium channel subunits. Real-time PCR reaction was performed in a final volume of $20 \mu$ l containing $50 \mathrm{ng}$ of cDNA, $300 \mathrm{~nm}$ of both primers, $10 \mu \mathrm{l}$ of $2 \times$ iQ SYBR-green mix containing nucleotides, iTaq DNA polymerase, SYBR-green, and fluorescein (Bio-Rad, Reinach, Switzerland) using the MyiQ Single Color real-time PCR Detection System (Bio$\mathrm{Rad}$, Reinach, Switzerland). The amplification protocol included $3 \mathrm{~min}$ at $95^{\circ} \mathrm{C}$, followed by 45 cycles of $10 \mathrm{~s}$ at $95^{\circ} \mathrm{C}$ for denaturation and $45 \mathrm{~s}$ at $60^{\circ} \mathrm{C}$ for annealing and extension. Specificity of amplification was determined by DNA melting curve using the built-in feature in the software for automatic fluorescence data capturing during gradual temperature increments $\left(0.5^{\circ} \mathrm{C}\right)$ 
from 55 to $95^{\circ} \mathrm{C}$. Efficiency of amplification was determined by serial dilution of starting DNA, and standard curves were constructed from the respective mean critical threshold value for endogenous control and sodium channel targets. Individual control samples (sham control group, $n=4$ ) and treated samples (SNI group, $n=4-6$ ) were amplified in triplicate. The relative expression of the target gene is calculated based on real-time PCR efficiencies and the threshold value of the unknown sample versus the standard sample (Pfaffl, 2001).

Isotopic in situ hybridization. Isotopic in situ hybridization was performed as described previously (Karchewski et al., 1999). Two sets of 48 bp oligonucleotide probes were designed to be complementary and selective for regions $418-371$ and $670-717$ of the $\beta 2$ subunit (GenBank accession number NM_012877), and one set was designed for $\mathrm{Na}_{\mathrm{v}} 1.3$ (GenBank accession number NM_013119). Probes were labeled at the $3^{\prime}$-end with ${ }^{35} \mathrm{~S}$-dATP or ${ }^{33} \mathrm{P}$-dATP terminal deoxynucleotidyl transferase reaction. Cryosectioned fresh-frozen DRG tissue from SNI, SNL, and control groups mounted on slides were covered with hybridization buffer (50\% formamide, $1 \times$ Denhardt's solution, $1 \%$ sarcosyl, $10 \%$ dextran sulfate, $0.02 \mathrm{M}$ phosphate buffer, pH7.0, $4 \times$ SSC, $500 \mu \mathrm{g} / \mathrm{ml}$ heatdenaturated salmon sperm DNA, $200 \mathrm{~mm}$ DTT, and $10^{7} \mathrm{cpm} / \mathrm{ml}$ labeled probe) and incubated for $18 \mathrm{~h}$ at $42^{\circ} \mathrm{C}$. Slides were then washed four times for $15 \mathrm{~min}$ in $1 \times \mathrm{SSC}$ at $55^{\circ} \mathrm{C}$, cooled down to room temperature for $30 \mathrm{~min}$ in the last wash step, dipped in distilled water, and finally dehydrated in ethanol. Autoradiograms were generated by coating slides with NTB2 nuclear track emulsion (Eastman Kodak) and exposing in the dark at $4^{\circ} \mathrm{C}$ for 2-4 weeks. Sections were then developed for $3 \mathrm{~min}$ in Kodak D19 developer (Eastman Kodak), fixed for 6 min in Rapid Fixer (Eastman Kodak), washed, and mounted with glycerol. Tissue was viewed under dark field, and images were captured.

Behavioral assessment. Mechanical sensitivity was assessed in agematched $\beta 2$ subunit null mutant mice ( $n=10$; male/female ratio, 5:5) and wild-type C57BL/ 6 mice ( $n=12$; male/female ratio, 7:5). Gross animal appearance is similar between groups, and the experimenter was blinded to the mouse genotypes. Mice were acclimated to the testing environment for 2 weeks, two baselines (BL1 and BL2) were measured 6 and $4 \mathrm{~d}$ before SNI surgery, and then testing sessions were conducted at 3 , $7,14,21$, and $28 \mathrm{~d}$ after SNI surgery. The lateral side of the plantar surface of the paw (sural nerve territory) was stimulated by calibrated von Frey monofilaments (Stoelting, Wood Dale, IL) (Decosterd and Woolf, 2000; Suter et al., 2003). Frequency of paw withdrawal to 10 stimuli for each monofilament was recorded, and each filament was applied in a logarithmic ascending force order $(0.008,0.02,0.04,0.070,0.16,0.40,0.60,1.0$, 1.4 , and $2.0 \mathrm{~g}$ ) (Mansikka et al., 2004). At 4 weeks, 50\% withdrawal threshold was determined using the up and down method (Chaplan et al., 1994).

Statistics. Data are represented as mean \pm SEM. Differences between groups were compared using Student's $t$ test or ANOVA, followed by Bonferroni's or Fisher's PLSD post hoc analysis when appropriate. A two-way ANOVA for repeated measures was used to evaluate the overall effect of the genotype on mechanical sensitivity. von Frey series present logarithmic differences between hairs, and logarithmic transformed values were used for the analysis, enabling ANOVA tests (Decosterd et al., 2004). Statistical analyses were performed using JMP statistical software (version 5.01; SAS Institute, Cary, NC). A $p$ value $\leq 0.05$ was considered statistically significant.

\section{Results}

\section{Antibody specificity}

We confirmed the specificity of a number of anti- $\beta 2$ subunit antibodies by Western blot, demonstrating the absence of crossreactivity with $\beta 1$ and $\beta 3$ subunits of VGSCs (Fig. 1A) (Coward et al., 2001). Anti- $\beta 2$ subunit antibodies GW83, GW93, and GW2690 were tested on membranes prepared from HEK293 cells transfected with the $\beta 1, \beta 2, \beta 3$, or control plasmids. In extract from the $\beta 2$ subunit cell line, a single band at apparent size above $30 \mathrm{kDa}$ was reduced to a size slightly below $25 \mathrm{kDa}$ when a deglycosylation step is added to the tissue processing (Fig. $1 \mathrm{~A}$ ), compatible with the expected $\beta 2$ subunit mass of $21 \mathrm{kDa}$ (Isom et al.,
1994). Similarly, in brain samples, a $37 \mathrm{kDa}$ band ran at $20-25$ $\mathrm{kDa}$ after deglycosylation (Fig. $1 B$ ). This correlates with a previous biochemical characterization that suggests that $>30 \%$ of the mass of the native rat brain $\beta 2$ subunit is carbohydrate (Messner and Catterall, 1985). The slightly higher mass observed in Figure $1 \mathrm{~A}$ might correspond to an incomplete deglycosylation during the processing of cell extracts.

There was no immunoreactivity in lanes containing brain tissue from $\beta 2$ subunit $-1-$ mice, and the single band visible from protein extracts of $\beta 2$ subunit $+/+$ mice disappeared when GW93 antibody was preabsorbed with low concentrations $(0.1$ $\mu \mathrm{M}$ and above) of the corresponding blocking peptide (Fig. $1 B$ ). The same preabsorption experiments were included as a control for blots and immunohistochemistry with GW83 and GW93 antibodies on DRG tissue from control and SNI rats, and the signal was abolished (data not shown).

\section{Peripheral nerve injury but not peripheral inflammation induces the $\boldsymbol{\beta} 2$ subunit in DRG neurons}

Immunoblotting reveals a dramatic increase in $\beta 2$ subunit expression in L4/L5 DRGs 1 week after SNI. Two different antibodies with cross-reactivity for the C-terminal tail of human and rat $\beta 2$ subunit (GW93 and GW2690) and the $\beta 2$-ec antibody targeting the extracellular domain of $\beta 2$ subunit all yielded similar results (Fig. $1 C-E$ ). $\beta 2$ subunit protein expression in the DRG was evaluated in three different models of peripheral nerve injury. Western blot analysis of $\beta 2$ subunit expression in the L4/L5 DRGs using GW93 antibody reveals increased expression 1 week after SNI, total transection of the sciatic nerve, and after SNL (L5 DRGs) (Figs. 1E, 2A) (see Fig. 7A). Compared with SNI lesion (tibial and common peroneal nerves), a complete sciatic nerve axotomy will include an additional lesion to the sural as well as the tibial and common peroneal nerves, and the number of injured neurons is commensurately larger. However, the proportion of sural nerve neurons in L4/L5 DRGs is $\leq 10 \%$ of the total number of DRG neurons (Devor et al., 1985; Schmalbruch, 1986), which is at the limit of the sensitivity of Western blots; hence, there is no detectable difference in $\beta 2$ subunit level between SNI and axotomy models.

The augmentation of $\beta 2$ subunit level is significantly different from controls at 3,5 , and $7 \mathrm{~d}$ after SNI $(p<0.01 ; n=4$ for each time point groups) (Fig. $2 B, C$ ). $\beta 2$ subunit levels at time points beyond day 3 are significantly different from the day 1 and day 3 time groups $(p<0.05)$, whereas no significant difference was observed between day 5 and day 7 , suggesting a slow onset of upregulation (at least $3 \mathrm{~d}$ ) that plateaus $5 \mathrm{~d}$ after nerve injury. The elevation in the $\beta 2$ subunit persists throughout the 4 week time course of the experiment (Fig. 2D). Constitutive ERK levels were used as a protein loading control because these do not change after nerve injury (Fig. $1 E$ ). The difference in ERK1/ERK2 levels between the control and SNI lanes in Figure $2 B$ is attributable to unbalanced protein loading and not regulation of ERK1/ERK2. To investigate whether $\beta 2$ subunit upregulation after nerve injury is specific to this type of lesion, we measured $\beta 2$ subunit expression levels after peripheral inflammation induced by intraplantar injection of CFA. Inflammation induced by CFA had no effect on $\beta 2$ subunit expression at both $48 \mathrm{~h}$ and 1 week (Fig. 2A).

An increase in $\beta 2$ subunit is detected in membrane fractions from the DRGs of SNI rats, whereas signal is almost absent in these fractions of control rats (Fig. 3).

Immunohistochemistry using GW83 $\beta 2$ antibody reveals a substantial increase in $\beta 2$-IR neurons in the ipsilateral L4/L5 


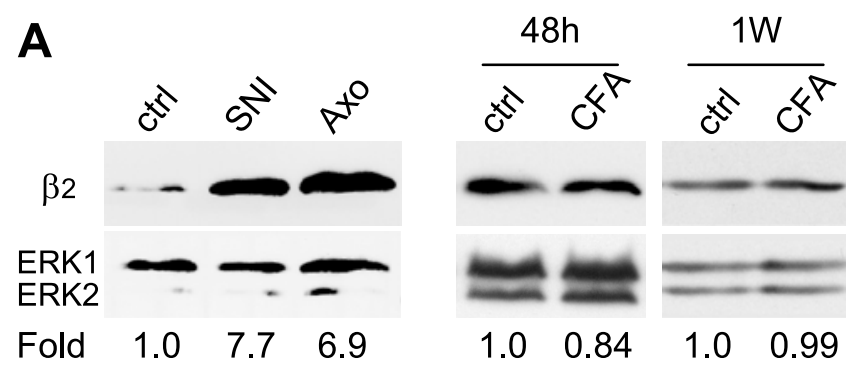

B

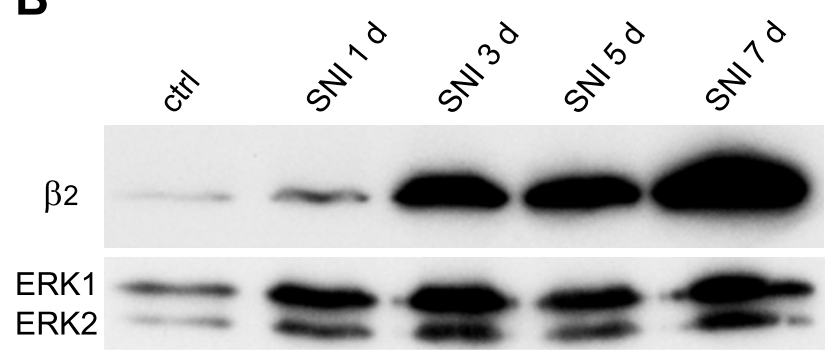

C
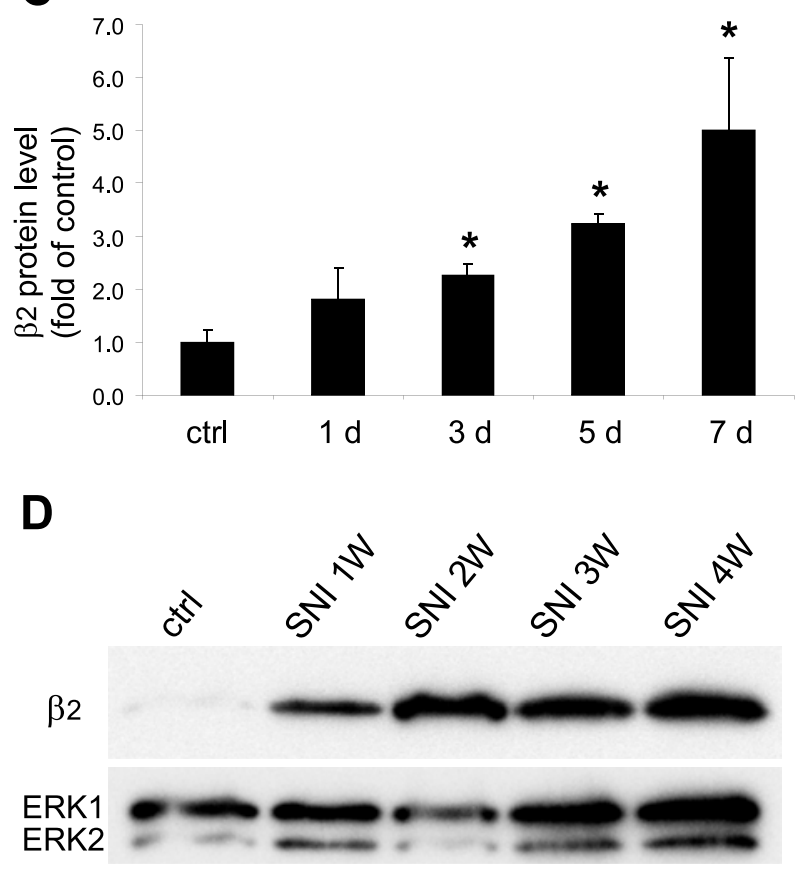

Figure 2. Peripheral nerve injury induces a rapid and persistent increase in $\beta 2$ subunit immunoreactivity in the DRG. $A$, Western blot analyses of the L4/L5 DRGs 1 week after an SNI, total axotomy of the sciatic nerve $(A x 0)$, or $48 \mathrm{~h}$ and 1 week (1W) after intraplantar $(F A$ induced inflammation (longer exposure). $\boldsymbol{B}, \boldsymbol{D}$, Representative Western blots from at least four independent experiments at 1, 3, 5, and $7 \mathrm{~d}$ after SNI and 1, 2, 3, and 4 weeks after SNI. C, Quantitation of $\beta 2$ subunit protein levels in the $L 4 / L 5$ DRGs at the indicated days after SNI. Fold represents comparative increase over control level after normalizing to total ERK2 $(n=4$ for each time point; $\left.{ }^{*} p<0.01\right)$. ctrl, Control.

DRGs 1 week after SNI compared with only a few neurons that are labeled in control DRG sections (Fig. $4 A$ ). Cell profile quantification indicated that $27.3 \pm 3.5 \%$ of total DRG neuronal profiles from SNI animals showed $\beta 2$ immunoreactivity compared with $2.1 \pm 0.7 \%$ of DRG neuronal profiles from control animals $(p<0.001 ; n=4$ in each group) (Fig. $4 B$ ).

To investigate whether the increase in the $\beta 2$ subunit occurs in cytosol

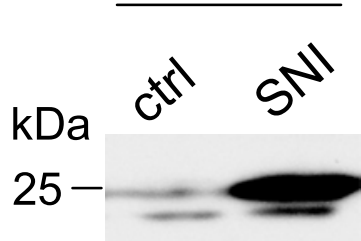

membrane

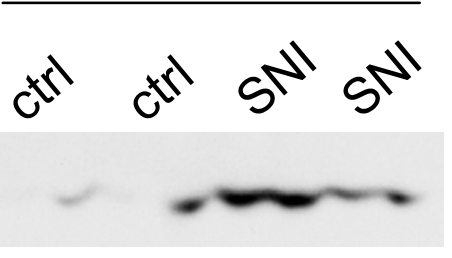

Figure 3. Redistribution of the $\beta 2$ subunit to the plasma membrane. Western blot analyses of cytosolic (left) and membrane (right) fractions show that SNI causes an increase in the amount of $\beta 2$ subunit at the plasma membrane, whereas signal in this fraction is almost absent in controls (ctrl) (L4 and L5 DRGs; $n=4$ in each lane conditions).

a particular subpopulation of DRG neurons, we colocalized $\beta 2$-IR neurons with NF-200, a marker for large sensory neurons (myelinated A fibers) (Michael and Priestley, 1999). One week after SNI, $\beta 2$ immunoreactivity was colocalized with NF-200-IR neurons, indicating that $\beta 2$ subunit is induced in neurons with myelinated fibers. $\beta 2$ immunoreactivity was also present in neurons that were not immunoreactive for NF-200, which possess unmyelinated axons (Fig. $4 C$ ). In addition, we examined the cross-sectional areas of $\beta 2$-IR cell profiles 1 week after SNI. A total of $56.2 \%$ of the $575 \beta 2$-IR profiles counted were small neurons $\left(<600 \mu \mathrm{m}^{2}\right), 23.3 \%$ corresponded to medium-sized sensory neurons $\left(600-1200 \mu \mathrm{m}^{2}\right)$, and $20.5 \%$ were large neurons $\left(>1200 \mu \mathrm{m}^{2}\right.$ ) (Fig. $4 \mathrm{D}$ ). Relative to the total number of DRG neuron profiles, $25.5,27.8$, and $37.1 \%$ of small-, medium-, largesized DRG neurons were $\beta 2$-IR positive. The number of $\beta 2$ positive neurons in control DRG sections was too low to establish a reliable distribution profile, but occasional small, medium, and large cells were observed.

Differential regulation of VGSC subunits in injured and noninjured neurons after peripheral nerve injury

We used real-time reverse transcription-PCR to compare VGSC subunit mRNA expression in L4/L5 DRG at different time points after SNI (Fig. 5A). VGSC transcript levels were normalized to GAPDH, a housekeeping gene that is unaltered by nerve injury, and expressed as the ratio of VGSC transcript level in DRGs from SNI rats to the VSGC transcript level in DRGs from controls. $\beta 2$ subunit mRNA levels in L4/L5 DRGs did not change over the $7 \mathrm{~d}$ after SNI ( $p>0.05 ; n=4-6$ in each group). As expected from other studies (Black et al., 1999; Sleeper et al., 2000), $\mathrm{Na}_{\mathrm{v}} 1.8$ mRNA significantly decreased $7 \mathrm{~d}$ after SNI compared with control $(p<0.05)$, and the level of $\mathrm{Na}_{\mathrm{v}} 1.3$ mRNA significantly increased at $7 \mathrm{~d}$ after SNI $(p<0.05)$. The unchanged level of $\beta 2$ subunit mRNA after SNI was confirmed by isotopic in situ hybridization studies using two separate sets of radiolabeled probes and performed 1 week after SNI or 2 weeks after SNL (Fig. 5B). Absence of a change in $\beta 2$ subunit mRNA after nerve injury was also confirmed by Northern blot analysis (data not shown). In control conditions, $\beta 2$ subunit mRNA transcript expression is more prevalent in DRG neurons than $\beta 2$ subunit protein expression (compare Figs. $4 A, 5 B$ ). Although a low sensitivity of detection by the immunohistochemistry assay cannot be excluded, the presence of the transcript in neurons in control naive DRGs, with high expression after nerve injury, support a posttranscriptional regulation of $\beta 2$ subunit produced by the nerve injury.

Isotopic in situ hybridization demonstrated an upregulation of $\mathrm{Na}_{\mathrm{v}} 1.3$ mRNA after both SNL and SNI (Fig. 5C). After SNL, $\mathrm{Na}_{\mathrm{v}} 1.3$ mRNA upregulation occurs exclusively in the L5 DRGs, in 

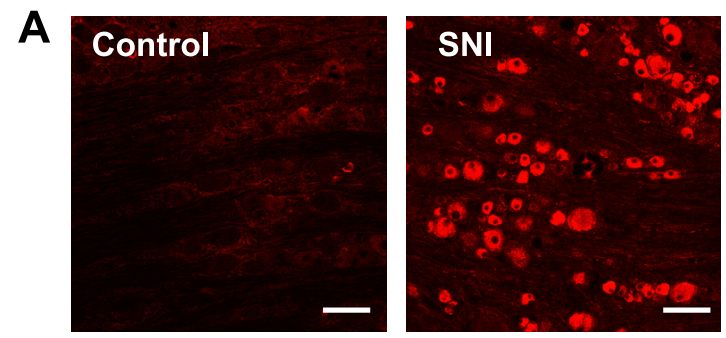

B

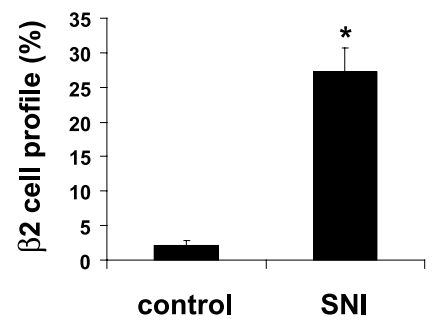

C
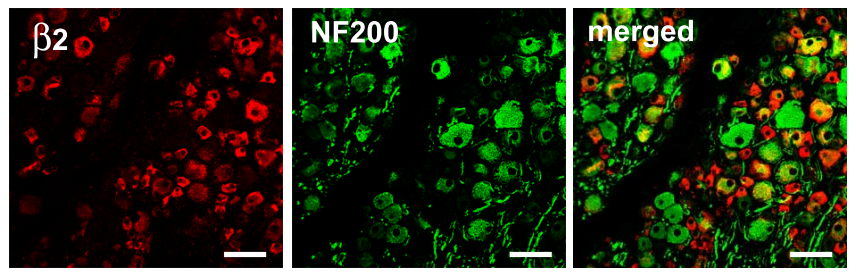

D

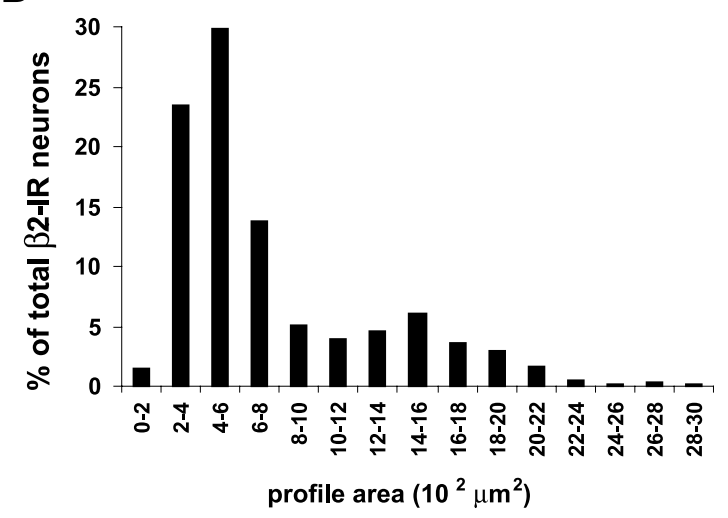

Figure 4. $\quad \beta 2$ subunit augmentation and distribution in primary sensory neuron populations after SNI. $\boldsymbol{A}$, Representative photomicrograph of fluorescent immunohistochemistry for $\beta 2$ subunit in L4 DRGs 1 week after SNI compared with control rats. $\boldsymbol{B}$, Percentage of total neuronal profile that express $\beta 2$ subunit in control DRGs and DRGs 1 week after SNI. ${ }^{*} p<0.001 ; n=4$ in each group. C, Double immunohistochemistry for $\beta 2$ subunit (red) and NF-200 (green) shows a distribution of $\beta 2$ immunoreactivity in both large cells (colocalization with NF-200 appears yellow on the merged image) and small cells (absence of colocalization, red). D, Profile area frequency histogram constructed from 575 cell profiles shows an increase of $\beta 2$ subunit-IR neurons 1 week after SNI in small-sized $\left(<600 \mu \mathrm{m}^{2}\right)$, medium-sized $\left(600-1200 \mu \mathrm{m}^{2}\right)$, and large-sized $\left(>1200 \mu \mathrm{m}^{2}\right.$ ) neurons. Scale bars, $100 \mu \mathrm{m}$.

which neurons are axotomized by the L5 spinal nerve injury procedure but not in the non-axotomized L4 DRG neurons (Fig. 5C).

After SNI, injured neurons from the transected tibial and common peroneal nerves and non-injured neurons from the sural nerve comingle in the L4 and L5 DRGs. To discriminate injured and non-injured neurons in the same DRGs, we used a strategy combining retrograde tracing of the intact sural nerve and immunohistochemical detection of injured neurons with antibody to ATF3 (a marker of axonal injury) (Benn et al., 2002; Decosterd et al., 2002; Obata et al., 2004). As expected, 1 week
A
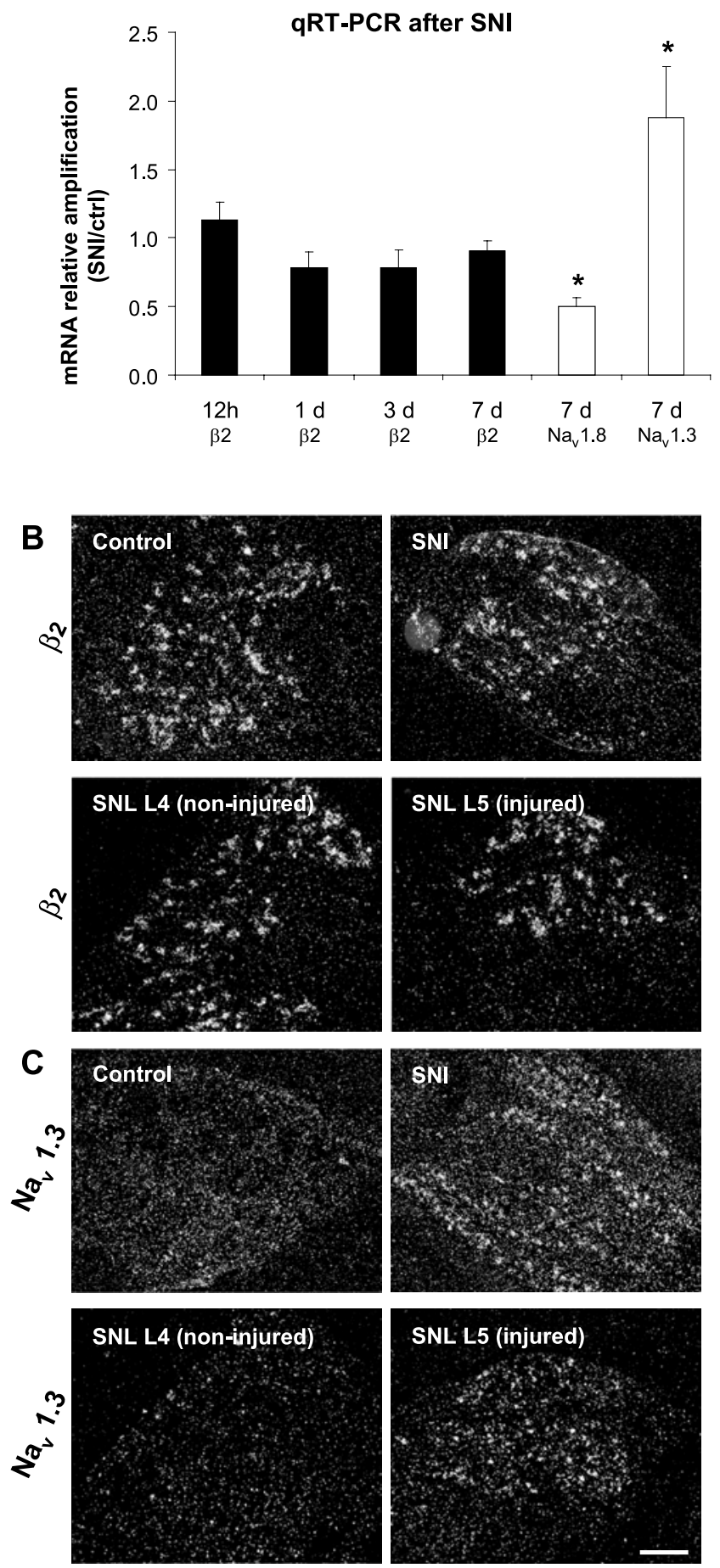

Figure 5. Regulation of VGSC subunit mRNA expression after nerve injury. $A$, Relative quantification by real-time reverse transcription-PCR amplification of mRNA for $\beta 2$ subunit and for $\alpha$ subunits $\mathrm{Na}_{\mathrm{v}} 1.3$ and $\mathrm{Na}_{\mathrm{v}} 1.8$ at indicated times. The $\mathrm{SNI} /$ control ratio refers to the ratio of mRNA levels in L4/L5 DRG tissue of SNI-injured and sham-operated animals (triplicate analysis of $4-6$ rats for each time point; $\left.{ }^{*} p<0.05\right) . B, C$, Representative dark-field photomicrographs of isotopic in situ hybridization in L4 DRGs from control animals or 1 week after $S N I$, as well as L4 (intact) DRGs and L5 (injured) DRGs 2 weeks after SNL. B, In situ hybridization for $\beta 2$ subunit mRNA. C, In situ hybridization for $\mathrm{Na}_{\mathrm{v}} 1.3 \alpha$ subunit mRNA. Scale bar, $350 \mu \mathrm{m}$.

after SNI, significant ATF3 immunoreactivity was present but did not overlap with Fluorogold (Fig. 6). $\beta 2$ immunoreactivity was predominantly observed in ATF3-IR neurons: $85.9 \pm 2.9 \%$ of injured ATF3-IR neurons expressed the $\beta 2$ subunit, and $83.6 \pm$ 


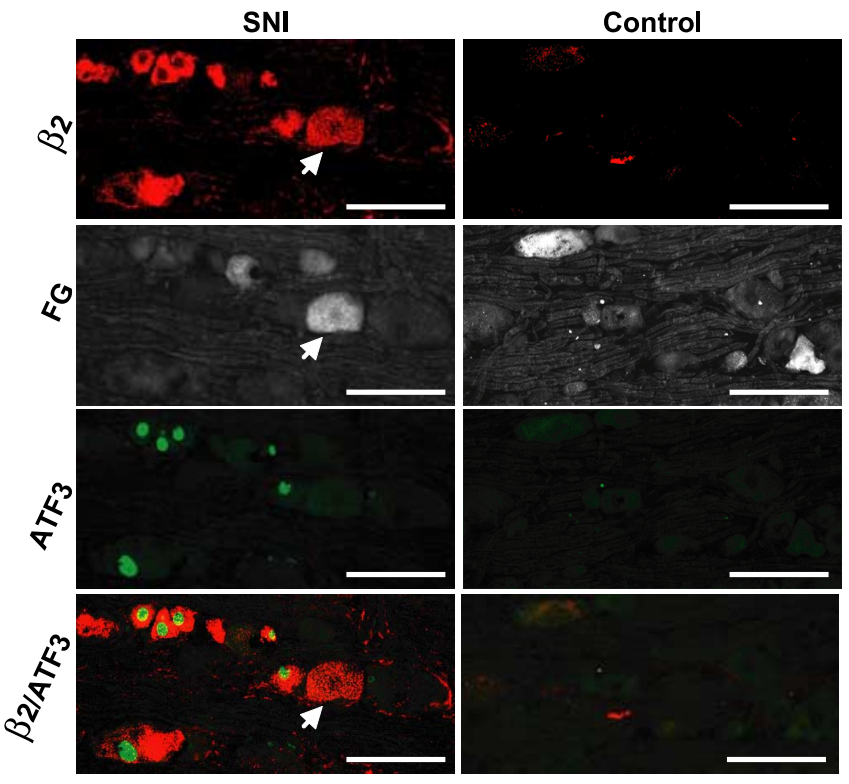

Figure 6. Characterization of $\beta 2$ immunoreactivity in injured and non-injured DRG neurons in the SNI model of neuropathic pain. Colocalization of immunoreactivity for $\beta 2$ with immunoreactivity for ATF3 and retrograde labeling with FG. The majority of $\beta 2$ immunoreactivity (red) is seen in ATF3-IR neurons (green), corresponding to injured cell population (green). To a limited extent, $\beta 2$ immunoreactivity is also seen in non-injured neurons of the sural nerve (white arrow) retrogradely traced with FG (bright gray). Scale bars, $100 \mu \mathrm{m}$.

$2.5 \% \beta 2$-IR neurons were ATF3 positive. Only $7.6 \pm 1.4 \%$ of retrogradely traced non-injured sural neurons were $\beta 2-\mathrm{IR}$, a much smaller subset than seen in injured ATF3-positive neurons $(p<0.0001 ; n=4$ in each group). In control sections, $\beta 2$ immunoreactivity in sural FG-positive cells was very rare (one or less FG/ $\beta 2$-positive cell on each DRG section). To evaluate that both injured and non-injured neurons upregulate the $\beta 2$ subunit after peripheral nerve injury, we investigated the $\beta 2$ subunit expression in the L4 and L5 DRGs 1 week after SNL (Fig. 7) and found that the $\beta 2$ subunit is increased after SNL in both L4 (intact) and L5 (injured) DRGs by Western blot analysis (Fig. 7A) and by immunohistochemistry (Fig. $7 B, C$ ). Similar to findings in the SNI model, the increase in $\beta 2$ subunit-IR profiles is much more pronounced in the injured neurons of the L5 DRGs, but it also augmented, although to a lesser extent, in the non-injured L4 DRG neurons ( $n=3 ; p<0.001$ and 0.01 , respectively) (Fig. $7 B, C)$.

\section{$\beta 2$ subunit expression is present in injured nerves and} clusters in the neuroma

Common peroneal and tibial nerves were separated from the sural nerve proximal to the ligation, and a nerve portion of a length of $4 \mathrm{~mm}$ including the neuroma tip was dissected. Western analysis revealed a twofold to threefold increase of $\beta 2$ subunit in the injured tibial and common peroneal nerves $(n=4$ for each time point) (Fig. 8A). However, no change in the level of $\beta 2$ subunit protein was detected in sural nerve in the 4 weeks after SNI (1 week after SNI, Fig. 8A; 2-4 weeks after SNI, data not shown). Regulation of $\beta 2$ subunit expression in these nerves was further investigated by immunohistochemistry of nerve sections. Confocal images ( $n=4-5$ in each group) reveal a large increase in intensity of staining for $\beta 2$ subunit in the injured tibial and peroneal nerves relative to control nerves and a smaller increase in staining in the sural nerve after SNI (Fig. $8 B, C$ ). Particularly

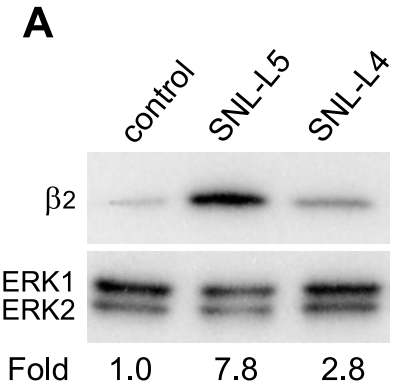

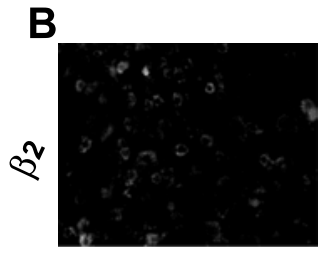

Control

C

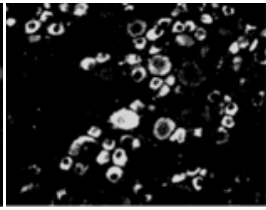

SNL L5 injured

SNL L5 injured

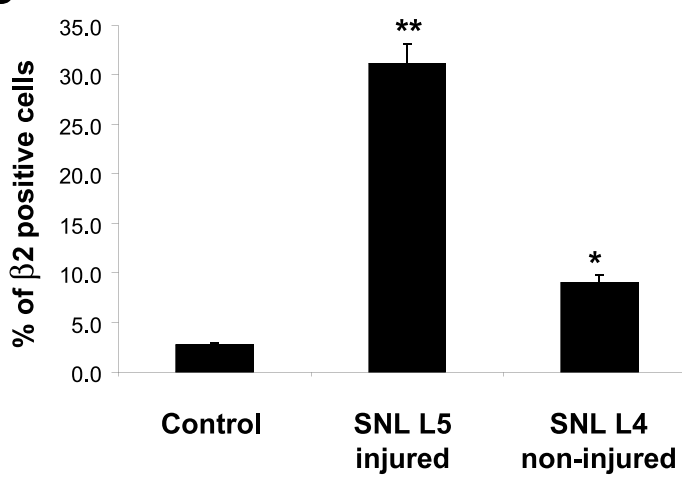

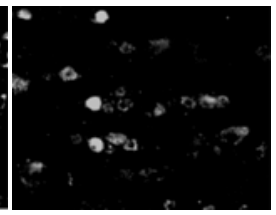

SNL L4

Figure 7. Characterization of $\beta 2$ immunoreactivity in injured and non-injured neurons in the L5 SNL model of neuropathic pain. $A, \beta 2$ immunoreactivity in L5 and L4 DRGs 1 week after SNL and in control. $\boldsymbol{B}$, Immunohistochemistry for $\beta 2$ subunit in sections of L4 and L5 DRGs 1 week after SNL and in a section of a control DRG. C, Percentage of neuronal profiles in injured (L5) and intact (L4) DRGs that express $\beta 2$ subunit compared with control contralateral DRG $\left({ }^{*} p<0.01 ;{ }^{* *} p<0.001 ; n=3\right)$. Fold represents comparative increase over control level after normalizing to ERK2 loading control.

intense $\beta 2$ subunit immunoreactivity was present at the transected axon tips within the neuroma (Fig. $8 B$ ).

\section{Mechanical allodynia-like behavior induced by SNI is} attenuated in $\boldsymbol{\beta} 2$ subunit null mutant mice

Responsiveness to mechanical stimuli in uninjured $\beta 2$ subunit $-/-$ and wild-type $+/+$ mice was assessed by measuring the frequency of response to repeated application of a standard set of calibrated von Frey hairs. No response was elicited at the very lowest von Frey hairs tested $(0.008$ and $0.02 \mathrm{~g})$ and $>70 \%$ response at $2 \mathrm{~g}$, the highest (Fig. $9 A$ ). No difference was found in responsiveness in the two sets of mice (Fig. 9A). The rate of response increased significantly relative to the non-injured control mice after SNI in both the wild type $+/+$ and $\beta 2$ subunit $-/-$ mice for all forces $<1 \mathrm{~g}$, with a recruitment of responses at previously subthreshold stimuli and greater responses to suprathreshold stimuli at $3,7,14,21$, and $28 \mathrm{~d}(p<0.01 ;-/-, n=10$; $+/+, n=12$ ) (Fig. 9B). No statistically significant difference between the two groups was found $3 \mathrm{~d}$ after SNI (data not shown). However, at day 7 and all other times tested up to $28 \mathrm{~d}$, 
A

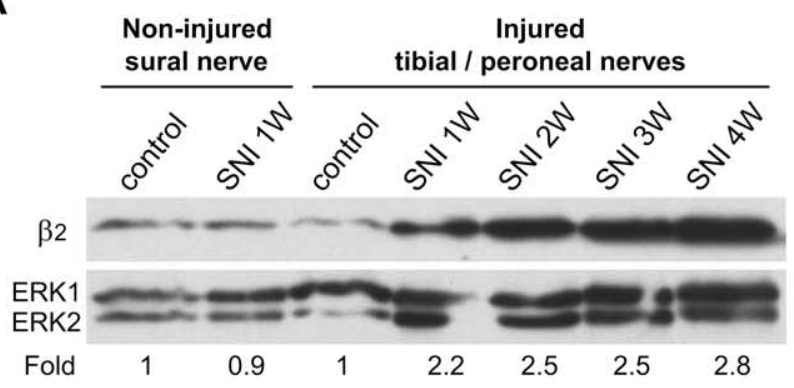

B

SNI: Injured tibial/peroneal nerves

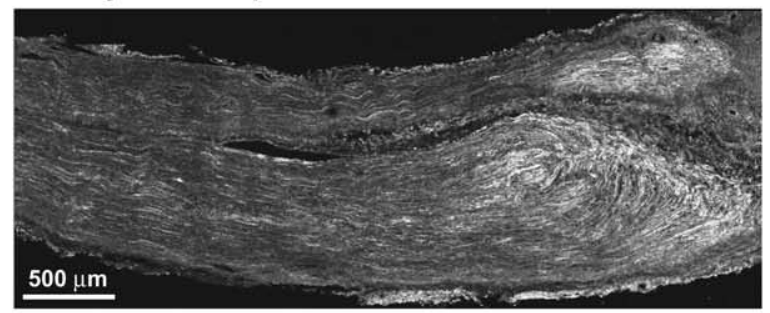

Control: tibial/peroneal nerves

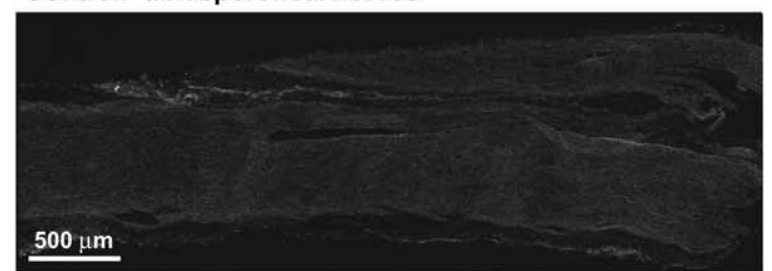

SNI: tibial-peronal nerves

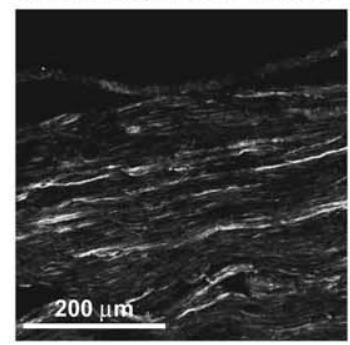

C

\section{Sural nerve in SNI rats}

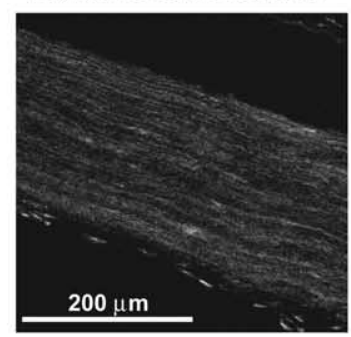

Control: tibial/peroneal nerves

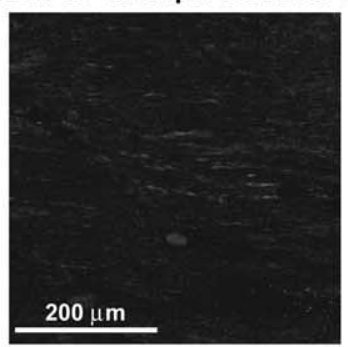

Sural nerve in control rats

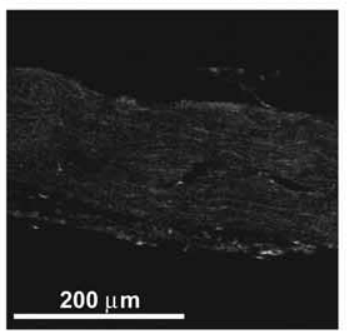

Figure 8. $\quad \beta 2$ subunit is increased in peripheral nerves after $\mathrm{SNI}$ and is transported along the injured nerve to the neuroma. Western blot $(\boldsymbol{A})$ and immunohistochemistry $(\boldsymbol{B}, \boldsymbol{C})$ analyses for $\beta 2$ subunit in injured and non-injured nerves 1 week (W) after SNI. $\boldsymbol{A}$, Representative blots, each from at least three independent experiments from control and SNI groups $(n=4-6$ in each group). The signal is augmented in the injured tibial and common peroneal nerves after $\mathrm{SNI}$ at all time points compared with nerves from control rats. $B, C$, Nerves were probed with anti- $\beta 2$ subunit antibody, and confocal images of representative sections show $\beta 2$ staining in injured common peroneal and tibial nerves 1 week after SNI (B) and in the spared sural nerve after SNI (C). High-magnification photomicrographs are of portions of nerves at a distance $\sim 2.5 \mathrm{~mm}$ away from the distal extremity of the neuroma. Fold represents comparative increase over control level after normalizing to ERK2 loading control.

the response in $-/-$ mice after SNI was significantly attenuated compared with $+/+$ mice $(p<0.001)$ (Fig. 9B). Four weeks after SNI, the $50 \%$ mechanical threshold of the hindpaw measured ipsilateral to the nerve injury was higher in $\beta 2$ subunit $-/-$ mice compared with the threshold in wild-type mice $(p=0.02)$ (Fig. $9 C)$, with no difference in the contralateral paws $(p>0.05)$.

\section{Discussion}

Using specific antibodies, we found a striking induction of VGSC $\beta 2$ subunit immunoreactivity after peripheral nerve injury. The increase in protein levels is most dramatic in the cell bodies, fibers, and nerve stump of injured neurons, but $\beta 2$ subunit expression was also increased in adjacent intact neurons. That this increase has functional significance was indicated by our observation that mechanical allodynia-like behavior after nerve injury was attenuated in $\beta 2$ subunit null mutant mice.

The $\beta 2$ subunit remained elevated in DRG neurons for at least 4 weeks after peripheral nerve injury, and this appears to be independent of transcriptional regulation because no increase in $\beta 2$ subunit mRNA transcript levels was detected, as with previous studies (Black et al., 1996; Shah et al., 2000; Takahashi et al., 2003). Nerve injury can induce expression of target genes by activating transcription factors such as ATF3, cAMP response element-binding protein, or c-jun, but protein synthesis in the nervous system can be also modulated without involving new transcription of mRNA by a modification of translational control. Such a mechanism is based on our data, likely to be initiated by nerve injury. It may include increases in translational rate as well as modulation by small micro-RNAs (Gebauer and Hentze, 2004; Klann and Dever, 2004). There is a precedent for posttranscriptional regulation in DRG neuron: the augmentation of TRPV1 protein after inflammation without a parallel change in TRPV1 mRNA levels (Ji et al., 2002). This is dependant on activation of the 38 mitogen-activated protein kinase pathway, and, after nerve injury, p38 is also activated in DRG neurons (Obata et al., 2004). p38 could potentially stimulate the eukaryotic initiation factor $4 \mathrm{E}$, an mRNA cap-binding protein essential for the initiation and rate of translation, and this or similar changes could augment $\beta 2$ subunit protein levels without change in transcript number (Scheper and Proud, 2002). A change in protein turnover rate could also augment $\beta 2$ subunit levels by decreasing protein degradation by the lysosomal proteolytic pathway.

Both the $\beta 2$ subunit and the $\mathrm{Na}_{\mathrm{v}} 1.3 \alpha$ subunit are increased in injured neurons. This parallels the emergence of a rapidly repriming TTX-sensitive sodium current in injured neurons that may contribute to a spontaneous firing of DRG neurons or firing at unusually higher frequencies (Black et al., 1999; Cummins et al., 2001; Takahashi et al., 2003). In contrast, TTX-resistant sodium currents and $\mathrm{Na}_{\mathrm{v}} 1.8$ and $\mathrm{Na}_{\mathrm{v}} 1.9$ channel expression decrease in injured neurons (Sleeper et al., 2000; Decosterd et al., 2002). TTX-resistant channels persist in intact adjacent neurons (Decosterd et al., 2002), and $\mathrm{Na}_{\mathrm{v}} 1.8$ is redistributed in the spared nerve so that this channel may contribute to pain hypersensitivity (Gold et al., 2003). Our data suggest that the upregulation and redistribution of $\beta 2$ subunit to the plasma membrane after nerve injury may contribute to an increase in the translocation of the sodium channel complex to the plasma membrane.

Neuropathic pain is associated with development of ectopic discharge in A- and C-fibers in both injured and non-injured nerves at the neuroma and in the cell somata that is associated with a subthreshold oscillation of the membrane potential of DRG neurons (Gold, 2000; Liu et al., 2000; Wu et al., 2001; Amir et al., 2005). VGSCs mediate intrinsic neuronal excitability and 
A

Mechanical sensitivity before SNI

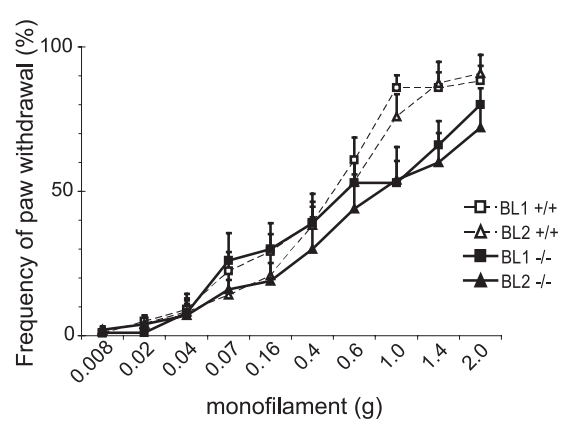

B

Mechanical hypersensitivity after SNI

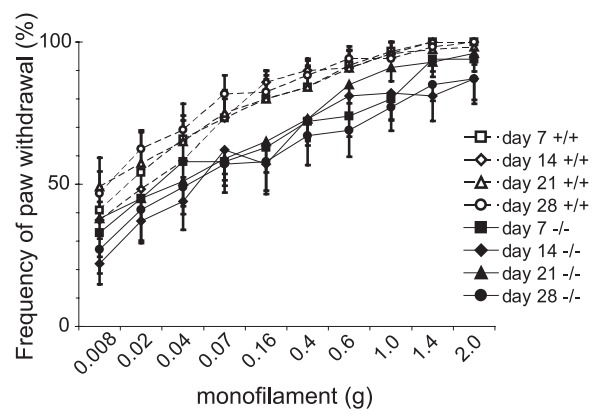

C

Mechanical threshold after SNI

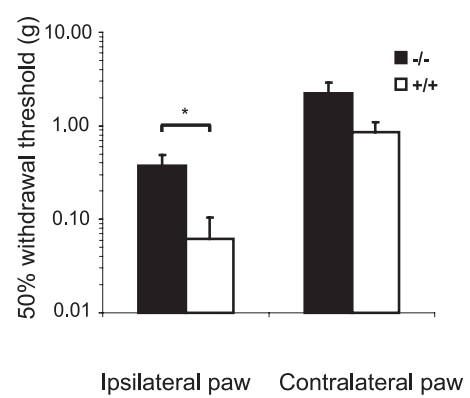

Figure 9. Attenuation of mechanical allodynia-like behavior after $S N I$ in $\beta 2$ subunit $-/-$ mice. $A, B$, Paw withdrawal frequencies to mechanical stimuli using a series of calibrated monofilaments with logarithmic increment. Frequency of response (paw withdrawal) to each monofilament in wild-type $(+/+)$ and $\beta 2$ subunit knock-out mice $(-/-)$ are shown before $(\boldsymbol{A}$; two baselines, $\mathrm{BL} 1$ and $\mathrm{BL} 2)$ and after $\mathrm{SNI}(\boldsymbol{B} ; 7,14,21$, and $28 \mathrm{~d}$ ). Baseline curves did not differ significantly between genotypes, whereas the response curves for the $+/+$ and $-/-$ mice at day 7 and after are significantly different, with the $-/-$ mice showing an attenuated response compared with the $+/+$ mice $(p<0.001 ; n=12$ and 10 , respectively). C, The $50 \%$ withdrawal threshold 4 weeks after SNI. The mechanical threshold is higher in $\beta 2$ subunit $-/-$ mice than wild-type mice ipsilateral but not contralateral to the nerve injury $\left({ }^{*} p=0.02 ; n=12\right.$ and 10 , respectively).

play a major role in the initiation and propagation of action potentials, repetitive firing, and amplification of synaptic potentials, as well as in generating subthreshold membrane potential oscillations (Klink and Alonso, 1993; Franceschetti et al., 1995; Catterall, 2000). Increased expression of the $\beta 2$ subunit after nerve injury may contribute to the altered sodium channel activity that is so characteristic of neuropathic pain. The $\beta 2$ subunit can regulate the number of VGSCs at the plasma membrane by controlling trafficking from the intracellular to the membrane compartment and alter VGSC kinetics (Schmidt and Catterall, 1986; Chen et al., 2002). The subunit is also a cell adhesion molecule that may mediate interactions with extracellular matrix and other signaling molecules. We discuss these properties of the $\beta 2$ subunit below and how each might be involved in VGSC function after nerve injury.

The $\beta 2$ subunit has a well established effect on VGSC cell surface expression (Isom et al., 1995). Many $\alpha$ subunits exist in a free intracellular pool, which serves as a source of precursors for subunit assembly by disulfide linkage with $\beta 2$ subunits. The appearance of VGSCs at the cell surface correlates with $\beta 2$ association (Catterall et al., 1986; Schmidt and Catterall, 1987; Isom et al., 1995; Isom, 2001). Cell expression studies have shown that association with $\beta 2$ regulates VGSC cell surface density and localization in developing neurons (Schmidt and Catterall, 1986, 1987; Kaplan et al., 2001; Chen et al., 2002). Several observations in $\beta 2$ subunit $-/-$ mice are consistent with a reduction in cell surface expression of VGSCs. Neurons from these animals bind less ${ }^{3} \mathrm{H}$-saxitoxin and have lower sodium current density than neurons from wild-type mice (Chen et al., 2002). These results suggest that the $\beta 2$ subunit is involved in the translocation of VGSC complex to and its immobilization in the cell membrane. After peripheral nerve injury, increased levels of $\beta 2$ subunit in the DRG cell body, along axons, and in the nerve stump may contribute to a local generation of ectopic activity by increasing VGSC density in the plasma membrane in both injured and non-injured neurons. This mechanism would be attenuated in $\beta 2$ subunit null mutant mice, which may explain why their mechanical hypersensitivity is less than that in wild-type mice.

The effect in vitro of the $\beta 2$ subunit on sodium channel properties is dependant on both cell type and the other subunit types present. When coexpressed in Xenopus oocytes with $\mathrm{Na}_{\mathrm{v}} 1.1$ or $\mathrm{Na}_{\mathrm{v}} 1.2, \beta 2$ promotes fast gating and a negative shift in voltage dependence of inactivation (Isom et al., 1995; Smith and Goldin, 1998). Conversely, $\beta 2$ causes a positive shift in voltage dependence of inactivation when expressed in HEK293 cells (Qu et al., 2001). When complexed with $\mathrm{Na}_{\mathrm{v}} 1.3$ in Chinese hamster ovary cells or HEK293 cells, $\beta 2$ does not affect gating (Cummins et al., 2001; Meadows et al., 2002). The $\beta 2$ subunit-mediated effect on the TTX-resistant $\mathrm{Na}_{\mathrm{v}} 1.8$ sodium channel in Xenopus oocytes is only a small depolarizing shift in the voltage dependence of inactivation. However, $\beta 2$ overrides the hyperpolarizing shift in activation that is observed when $\beta 1$ is coexpressed with $\mathrm{Na}_{\mathrm{v}} 1.8$ (Vijayaragavan et al., 2004). Studies in $\beta 2$ null mutant mice reveal only subtle and small change in the voltage dependence of inactivation of VGSCs (Chen et al., 2002). It is possible therefore that the $\beta 2$ subunit has only limited effects on VGSC electrophysiological properties and that $\beta 2$ subunit prime function is to regulate the membrane density of the VGSC complex, whereas the $\beta 3$ subunit, which is also upregulated in injured neurons, modifies sodium channel kinetics (Morgan et al., 2000; Takahashi et al., 2003). Nevertheless, the small changes observed in channel properties in vitro may be critical for a fine-tuning of the more complex membrane excitability of sensory neurons in vivo.

The $\beta 2$ subunit is also a cell adhesion molecule with sequence homology to the neural cell adhesion molecule contactin, a member of the Ig superfamily. Contactin, which associates with VGSC $\alpha$ subunits via $\beta 1$, is upregulated in axotomized neurons and accumulates together with $\mathrm{Na}_{\mathrm{v}} 1.3$ at injured axon tips in the neuroma (Shah et al., 2004). $\beta 2$ and contactin may share a similar mechanism for increasing hyperexcitability in neuropathic pain (Isom et al., 1995; Kazarinova-Noyes et al., 2001). $\beta 2$ interacts with the extracellular matrix proteins tenascin-R and tenascin- $\mathrm{C}$ (Xiao et al., 1999), recruits ankyrin to the plasma membrane at points of cell-cell contact, and transduces signals between adjacent cells or adjacent axons and the cytoskeleton (Malhotra et al., 2000). After nerve injury, cell adhesion molecules of the Ig superfamily may play a role in neuronal regeneration and the reformation of nodes of Ranvier (Kaplan et al., 2001; Kazarinova-Noyes et al., 2001; Isom, 2002). An increase in $\beta 2$ subunit in the active growth cone of sensory axons might participate, therefore, in the regeneration response to nerve injury (Davis et al., 2004).

In conclusion, we find a rapid and persistent transcriptionindependent increase in the $\beta 2$ VGSC subunit after peripheral nerve injury. Upregulation of the $\beta 2$ subunit in injured and non- 
injured sensory afferents may regulate both the translocation and immobilization of sodium channels in the cell membrane and modify their kinetics, leading to membrane hyperexcitability and ectopic activity, and thereby, contribute to neuropathic pain.

\section{References}

Amaya F, Decosterd I, Samad TA, Plumpton C, Tate S, Mannion RJ, Costigan M, Woolf CJ (2000) Diversity of expression of the sensory neuronspecific TTX-resistant voltage-gated sodium ion channels SNS and SNS2. Mol Cell Neurosci 15:331-342.

Amir R, Devor M (2000) Functional cross-excitation between afferent Aand C-neurons in dorsal root ganglia. Neuroscience 95:189-195.

Amir R, Kocsis JD, Devor M (2005) Multiple interacting sites of ectopic spike electrogenesis in primary sensory neurons. J Neurosci 25:2576-2585.

Benn SC, Perrelet D, Kato A, Scholz J, Decosterd I, Mannion R, Bakowska J, Woolf C (2002) Hsp27 upregulation and phosphorylation is required for injured sensory and motor neuron survival. Neuron 36:45-56.

Black JA, Dib-Hajj S, McNabola K, Jeste S, Rizzo MA, Kocsis JD, Waxman SG (1996) Spinal sensory neurons express multiple sodium channel alphasubunit mRNAs. Brain Res Mol Brain Res 43:117-131.

Black JA, Cummins TR, Plumpton C, Chen YH, Hormuzdiar W, Clare JJ, Waxman SG (1999) Upregulation of a silent sodium channel after peripheral, but not central, nerve injury in DRG neurons. J Neurophysiol $82: 2776-2785$.

Catterall WA (2000) From ionic currents to molecular mechanisms: the structure and function of voltage-gated sodium channels. Neuron 26:13-25.

Catterall WA, Schmidt JW, Messner DJ, Feller DJ (1986) Structure and biosynthesis of neuronal sodium channels. Ann NY Acad Sci 479:186-203.

Chaplan SR, Bach FW, Pogrel JW, Chung JM, Yaksh TL (1994) Quantitative assessment of tactile allodynia in the rat paw. J Neurosci Methods 53:55-63.

Chen C, Bharucha V, Chen Y, Westenbroek RE, Brown A, Malhotra JD, Jones D, Avery C, Gillespie PJ, Kazen-Gillespie KA, Kazarinova-Noyes K, Shrager P, Saunders TL, Macdonald RL, Ransom BR, Scheuer T, Catterall WA, Isom LL (2002) Reduced sodium channel density, altered voltage dependence of inactivation, and increased susceptibility to seizures in mice lacking sodium channel beta 2-subunits. Proc Natl Acad Sci USA 99:17072-17077.

Coward K, Jowett A, Plumpton C, Powell AJ, Birch R, Tate S, Bountra C, Anand P (2001) Sodium channel betal and beta2 subunits parallel SNS/ PN3 alpha-subunit changes in injured human sensory neurons. NeuroReport 12:483-488.

Cummins TR, Aglieco F, Renganathan M, Herzog RI, Dib-Hajj SD, Waxman SG (2001) Nav1.3 sodium channels: rapid repriming and slow closedstate inactivation display quantitative differences after expression in a mammalian cell line and in spinal sensory neurons. J Neurosci 21:5952-5961.

Davis TH, Chen C, Isom LL (2004) Sodium channel betal subunits promote neurite outgrowth in cerebellar granule neurons. J Biol Chem 279:51424-51432.

Decosterd I, Woolf CJ (2000) Spared nerve injury: an animal model of persistent peripheral neuropathic pain. Pain 87:149-158.

Decosterd I, Ji RR, Abdi S, Tate S, Woolf CJ (2002) The pattern of expression of the voltage-gated sodium channels $\mathrm{Na}(\mathrm{v}) 1.8$ and $\mathrm{Na}(\mathrm{v}) 1.9$ does not change in uninjured primary sensory neurons in experimental neuropathic pain models. Pain 96:269-277.

Decosterd I, Allchorne A, Woolf CJ (2004) Differential analgesic sensitivity of two distinct neuropathic pain models. Anesth Analg 99:457-463.

Devor M, Govrin-Lippmann R, Frank I, Raber P (1985) Proliferation of primary sensory neurons in adult rat dorsal root ganglion and the kinetics of retrograde cell loss after sciatic nerve section. Somatosens Res 3:139-167.

Franceschetti S, Guatteo E, Panzica F, Sancini G, Wanke E, Avanzini G (1995) Ionic mechanisms underlying burst firing in pyramidal neurons: intracellular study in rat sensorimotor cortex. Brain Res 696:127-139.

Gebauer F, Hentze MW (2004) Molecular mechanisms of translational control. Nat Rev Mol Cell Biol 5:827-835.

Gold MS (2000) Spinal nerve ligation: what to blame for the pain and why. Pain 84:117-120.

Gold MS, Weinreich D, Kim CS, Wang R, Treanor J, Porreca F, Lai J (2003)
Redistribution of NaV1.8 in uninjured axons enables neuropathic pain. J Neurosci 23:158-166.

Hains BC, Saab CY, Klein JP, Craner MJ, Waxman SG (2004) Altered sodium channel expression in second-order spinal sensory neurons contributes to pain after peripheral nerve injury. J Neurosci 24:4832-4839.

Isom LL (2001) Sodium channel beta subunits: anything but auxiliary. The Neuroscientist 7:42-54.

Isom LL (2002) The role of sodium channels in cell adhesion. Front Biosci 7:12-23.

Isom LL, De Jongh KS, Patton DE, Reber BF, Offord J, Charbonneau H, Walsh K, Goldin AL, Catterall WA (1992) Primary structure and functional expression of the beta 1 subunit of the rat brain sodium channel. Science 256:839-842.

Isom LL, De Jongh KS, Catterall WA (1994) Auxiliary subunits of voltagegated ion channels. Neuron 12:1183-1194.

Isom LL, Ragsdale DS, De Jongh KS, Westenbroek RE, Reber BF, Scheuer T, Catterall WA (1995) Structure and function of the beta 2 subunit of brain sodium channels, a transmembrane glycoprotein with a CAM motif. Cell 83:433-442.

Ji RR, Samad TA, Jin SX, Schmoll R, Woolf CJ (2002) p38 MAPK activation by NGF in primary sensory neurons after inflammation increases TRPV1 levels and maintains heat hyperalgesia. Neuron 36:57-68.

Kaplan MR, Cho MH, Ullian EM, Isom LL, Levinson SR, Barres BA (2001) Differential control of clustering of the sodium channels $\mathrm{Na}(\mathrm{v}) 1.2$ and $\mathrm{Na}(\mathrm{v}) 1.6$ at developing CNS nodes of Ranvier. Neuron 30:105-119.

Karchewski LA, Kim FA, Johnston J, McKnight RM, Verge VM (1999) Anatomical evidence supporting the potential for modulation by multiple neurotrophins in the majority of adult lumbar sensory neurons. J Comp Neurol 413:327-341.

Kazarinova-Noyes K, Malhotra JD, McEwen DP, Mattei LN, Berglund EO, Ranscht B, Levinson SR, Schachner M, Shrager P, Isom LL, Xiao ZC (2001) Contactin associates with $\mathrm{Na}^{+}$channels and increases their functional expression. J Neurosci 21:7517-7525.

Kim SH, Chung JM (1992) An experimental model for peripheral neuropathy produced by segmental spinal nerve ligation in the rat. Pain 50:355-363.

Klann E, Dever TE (2004) Biochemical mechanisms for translational regulation in synaptic plasticity. Nat Rev Neurosci 5:931-942.

Klink R, Alonso A (1993) Ionic mechanisms for the subthreshold oscillations and differential electroresponsiveness of medial entorhinal cortex layer II neurons. J Neurophysiol 70:144-157.

Liu CN, Michaelis M, Amir R, Devor M (2000) Spinal nerve injury enhances subthreshold membrane potential oscillations in DRG neurons: relation to neuropathic pain. J Neurophysiol 84:205-215.

Ma C, Shu Y, Zheng Z, Chen Y, Yao H, Greenquist KW, White FA, LaMotte RH (2003) Similar electrophysiological changes in axotomized and neighboring intact dorsal root ganglion neurons. J Neurophysiol 89:1588-1602.

Malhotra JD, Kazen-Gillespie K, Hortsch M, Isom LL (2000) Sodium channel beta subunits mediate homophilic cell adhesion and recruit ankyrin to points of cell-cell contact. J Biol Chem 275:11383-11388.

Mansikka H, Zhao C, Sheth RN, Sora I, Uhl G, Raja SN (2004) Nerve injury induces a tonic bilateral mu-opioid receptor-mediated inhibitory effect on mechanical allodynia in mice. Anesthesiology 100:912-921.

Meadows LS, Chen YH, Powell AJ, Clare JJ, Ragsdale DS (2002) Functional modulation of human brain Nav1.3 sodium channels, expressed in mammalian cells, by auxiliary beta 1 , beta 2 and beta 3 subunits. Neuroscience 114:745-753.

Messner DJ, Catterall WA (1985) The sodium channel from rat brain. Separation and characterization of subunits. J Biol Chem 260:10597-10604.

Michael GJ, Priestley JV (1999) Differential expression of the mRNA for the vanilloid receptor subtype 1 in cells of the adult rat dorsal root and nodose ganglia and its downregulation by axotomy. J Neurosci 19:1844-1854.

Morgan K, Stevens EB, Shah B, Cox PJ, Dixon AK, Lee K, Pinnock RD, Hughes J, Richardson PJ, Mizuguchi K, Jackson AP (2000) Beta 3: an additional auxiliary subunit of the voltage-sensitive sodium channel that modulates channel gating with distinct kinetics. Proc Natl Acad Sci USA 97:2308-2313.

Obata K, Yamanaka H, Kobayashi K, Dai Y, Mizushima T, Katsura H, Fukuoka T, Tokunaga A, Noguchi K (2004) Role of mitogen-activated protein kinase activation in injured and intact primary afferent neurons 
for mechanical and heat hypersensitivity after spinal nerve ligation. J Neurosci 24:10211-10222.

Pfaffl MW (2001) A new mathematical model for relative quantification in real-time RT-PCR. Nucleic Acids Res 29:2002-2007.

Price DD, Bennett GJ, Rafii A (1989) Psychophysical observations on patients with neuropathic pain relieved by a sympathetic block. Pain 36:273-288.

Qu Y, Curtis R, Lawson D, Gilbride K, Ge P, DiStefano PS, Silos-Santiago I, Catterall WA, Scheuer T (2001) Differential modulation of sodium channel gating and persistent sodium currents by the beta1, beta2, and beta3 subunits. Mol Cell Neurosci 18:570-580.

Scheper GC, Proud CG (2002) Does phosphorylation of the cap-binding protein eIF4E play a role in translation initiation? Eur J Biochem 269:5350-5359.

Schmalbruch H (1986) Fiber composition of the rat sciatic nerve. Anat Rec 215:71-81.

Schmidt JW, Catterall WA (1986) Biosynthesis and processing of the alpha subunit of the voltage-sensitive sodium channel in rat brain neurons. Cell 46:437-444.

Schmidt JW, Catterall WA (1987) Palmitylation, sulfation, and glycosylation of the alpha subunit of the sodium channel. Role of post-translational modifications in channel assembly. J Biol Chem 262:13713-13723.

Shah BS, Stevens EB, Gonzalez MI, Bramwell S, Pinnock RD, Lee K, Dixon AK (2000) beta3, a novel auxiliary subunit for the voltage-gated sodium channel, is expressed preferentially in sensory neurons and is upregulated in the chronic constriction injury model of neuropathic pain. Eur J Neurosci 12:3985-3990.

Shah BS, Rush AM, Liu S, Tyrrell L, Black JA, Dib-Hajj SD, Waxman SG (2004) Contactin associates with sodium channel Nav1.3 in native tissues and increases channel density at the cell surface. J Neurosci 24:9387-9399.

Sleeper AA, Cummins TR, Dib-Hajj SD, Hormuzdiar W, Tyrrell L, Waxman SG, Black JA (2000) Changes in expression of two tetrodotoxin-resistant sodium channels and their currents in dorsal root ganglion neurons after sciatic nerve injury but not rhizotomy. J Neurosci 20:7279-7289.

Smith RD, Goldin AL (1998) Functional analysis of the rat I sodium channel in Xenopus oocytes. J Neurosci 18:811-820.

Suter MR, Papaloizos M, Berde CB, Woolf CJ, Gilliard N, Spahn DR, De- costerd I (2003) Development of neuropathic pain in the rat spared nerve injury model is not prevented by a peripheral nerve block. Anesthesiology 99:1402-1408.

Takahashi N, Kikuchi S, Dai Y, Kobayashi K, Fukuoka T, Noguchi K (2003) Expression of auxiliary beta subunits of sodium channels in primary afferent neurons and the effect of nerve injury. Neuroscience 121:441-450.

Vandesompele J, De Paepe A, Speleman F (2002) Elimination of primerdimer artifacts and genomic coamplification using a two-step SYBR green I real-time RT-PCR. Anal Biochem 303:95-98.

Vijayaragavan K, Powell AJ, Kinghorn IJ, Chahine M (2004) Role of auxiliary beta1-, beta2-, and beta3-subunits and their interaction with $\mathrm{Na}(\mathrm{v}) 1.8$ voltage-gated sodium channel. Biochem Biophys Res Commun 319:531-540.

Wall PD, Devor M (1983) Sensory afferent impulses originate from dorsal root ganglia as well as from the periphery in normal and nerve injured rats. Pain 17:321-339.

Wood JN, Boorman JP, Okuse K, Baker MD (2004) Voltage-gated sodium channels and pain pathways. J Neurobiol 61:55-71.

Wu G, Ringkamp M, Hartke TV, Murinson BB, Campbell JN, Griffin JW, Meyer RA (2001) Early onset of spontaneous activity in uninjured c-fiber nociceptors after injury to neighboring nerve fibers. J Neurosci 21:RC140(1-5).

Xiao ZC, Ragsdale DS, Malhotra JD, Mattei LN, Braun PE, Schachner M, Isom LL (1999) Tenascin-R is a functional modulator of sodium channel beta subunits. J Biol Chem 274:26511-26517.

Yu FH, Catterall WA (2004) The VGL-chanome: a protein superfamily specialized for electrical signaling and ionic homeostasis. Sci STKE 2004:re15.

Yu FH, Westenbroek RE, Silos-Santiago I, McCormick KA, Lawson D, Ge P, Ferriera H, Lilly J, DiStefano PS, Catterall WA, Scheuer T, Curtis R (2003) Sodium channel $\beta 4$, a new disulfide-linked auxiliary subunit with similarity to $\beta 2$. J Neurosci $23: 7577-7585$.

Zhuang ZY, Gerner P, Woolf CJ, Ji RR (2005) ERK is sequentially activated in neurons, microglia, and astrocytes by spinal nerve ligation and contributes to mechanical allodynia in this neuropathic pain model. Pain 114:149-159.

Zimmermann M (1983) Ethical guidelines for investigations of experimental pain in conscious animals. Pain 16:109-110. 